\title{
Gymnodinium blooms in the Helgoland Bight (North Sea) during August, 1968
}

\author{
W. Hickel, E. Hagmeier and G. Drebes \\ Biologische Anstalt Helgoland \\ Zentrale, Hamburg 50, and Meeresstation, Helgoland, \\ Federal Republic of Germany
}

\begin{abstract}
KURZFASSUNG: Gymnodinium-Wucherungen in der Helgoländer Bucht (Nordsee) im August 1968. Wie in anderen Teilen der Nordsee traten auch in der Helgoländer Bucht im August 1968 starke Wucherungen von Dinoflagellaten auf. Untersuchungen des Planktons und der Wassereigenschaften auf der Helgoland-Reede sowie auf weiteren Stationen in der Helgoländer Bucht wurden für die Erklärung dieser Erscheinung ausgewertet. In allen untersuchten Gebieten (Fig. 1) fand sich Gymnodinitum sp. als dominante Planktonform. GymnodinienWucherungen traten auf der Helgoland-Reede in der Zeit vom 14.-30. August auf und erreichten Zellzahlen von über $3 \times 10^{6} / 1$ am 28. und 30. August, bei nur 18-19 $\mu \mathrm{g}$ Chlorophyll all. Eine Million Gymnodinien produzierten 0,265 mg C in 6 Stunden im Inkubator. Etwa $3 \times 10^{6}$ Gymnodinium sp. wurden in den obersten $16,5 \mathrm{~m}$ der Wassersäule in der Nähe Helgolands während des Blüte-Maximums gemessen (maximal 7,8 $\times 10^{6} / 1$ in $3 \mathrm{~m}$ ). Die Gymnodinien waren tagsüber in den obersten Metern konzentriert. Eine solche Vertikalschidhtung war besonders im Küstenwasser vor der Elbmündung ausgeprägt, wo bis zu $0, \hat{3} \times 10^{\circ} \mathrm{Zellen} / \mathrm{l}$ gefunden wurden. Gymnodinium sp. bildete 96-99\% der Biomasse während der Blüte bei Helgoland. Es wurden ein Chlorophyll-a-Gehalt von nur 3,5 $\mu \mathrm{g}$ für $10^{6}$ Zellen ermittelt und eine Extinktion von $\mathrm{E}=0,083 / 1 \mathrm{~m}$ für eine Suspension von $10^{6} \mathrm{Gymnodinien} / \mathrm{l}$ in Proben mit minimalem Gehalt an übrigem Plankton und Detritus gemessen. Der Nitrat- und Nitritgehalt im Wasser war zeitweise erschöpft, nicht aber das Phosphat. Wenn Wassermassen mit Gymnodinium-Blüten nach Helgoland gedriftet wurden, fiel der Salzgehalt, und die Temperatur stieg an, was auf eine Entstehung der Wucherungen im brackwasser-beeinflußten Gebiet östlich Helgolands hindeutet. Die Gymnodinium-Blüten entwickelten sich nach einer außergewöhnlich langen windarmen Periode und während eines minimalen Süßwasserzuflusses aus der Elbe. Vergiftungserscheinungen an Seetieren wurden bei Helgoland nicht festgestellt.
\end{abstract}

\section{INTRODUCTION}

During the second half of August, 1968, an intense blooming of a Gymnodinium species was observed in the waters near Helgoland (German Bight). Attaining cell concentrations of more than 3 millions per liter, this dinoflagellate caused water discolorations and dominated the plankton for a period of 18 days. Unusual mass development of phytoplankton was recorded in two other regions of the North Sea during spring to autumn, 1968. Red tides, caused by the dinoflagellate Gonyaulax tamarensis, 
occurred at several locations off the English East Coast. They started in April and May and caused extensive mortality of fish, shellfish and seabirds (Robinson 1968, Adams et al. 1968, Ingham et al. 1968, Clark 1968, McCollum et al. 1968, Coulson et al. 1968).

VAGN HANSEN \& SARMA (1969) report the occurrence of red water at various locations off the Jutland West Coast, starting in July, 1968. They investigated samples from regions near Esbjerg to Skagen and found Gymnodinium breve forma as the causative red tide organism. Poisoning of marine animals was reported there during the period from July to October. The investigations of the plankton blooms in the Helgoland waters complete the picture of the unusual events in the phytoplankton development in the North Sea during 1968.

\section{MATERIAL AND METHODS}

Plankton content and environmental factors of the Helgoland waters have been monitored continuously for more than 10 years at the station "Helgoland Roads" in the channel between the two isles of Helgoland " $A$ " in Fig. 1). Water masses from northwest and south of Helgoland move with the tides through this channel, which is $600 \mathrm{~m}$ wide and 5 to $7 \mathrm{~m}$ deep at its narrowest part. The measurements were made at a water depth of one meter once a day or three times a week and included determinations of salinity, temperature, seston weight and chlorophyll content, qualitative and quantitative plankton counts, measurement of phytoplankton assimilation, of a variety of micronutrients, and of soluble organic matter.

On 27 and 28 August, 1968, vertical measurements of plankton and chlorophyll distribution were made at three locations south, southwest and northwest of Helgoland (B, C and D in Fig. 1). Furthermore the vertical stratifications of plankton and hydrographical data were measured at two drifting stations off the Elbe estuary and off the Eider mouth on 6 and 8 August ( $E$ and $F$ in Fig. 1). These three groups of data were used to analyze the occurrence and causes of the Gymnodinium blooms during August, 1968. As they were not taken with the aim of investigating these blooms, but for other plankton studies, the data are incomplete in regard to this purpose.

Water samples were taken by Hydro Bios series water samplers made of plexiglass. $100 \mathrm{ml}$ subsamples were preserved with Lugol's iodine solution (we used three times the recommended concentration). Generally $25 \mathrm{ml}$ samples were counted for species composition and quantity of the phytoplankton using the sedimentation technique with an inverted microscope. Cell counts were converted to organic carbon content as a measure for the biomass and to enable reasonable summation of plankters of different size. Conversion factors from different authors were used (LoHMANN 1908, Mullin et al. 1966, Smayda 1965).

Phytoplankton assimilation was measured by the oxygen method with light and dark bottles in the incubator. Within the 6 hours incubation time samples were illuminated with $20 \mathrm{cal} / \mathrm{cm}^{2}$. Chlorophyll a content of the seston was obtained by photometry of the acetone extract. Nitrite and nitrate in the water were determined following Strickland \& Parsons (1965), phosphate according to Kalle (1934), modified. 
For $\mathrm{NO}_{2}$ and $\mathrm{PO}_{4}$ determinations an autoanalyzer was used. As a measure for soluble organic carbon the permanganate oxidation method described by GILLBRICHT (1957) was applied. Transparency of the water was determined by a Secchi disc. An estimation of the compensation depth (with $1 \%$ of total incident radiation) was obtained by taking three times the Secchi depth according to VISSER (1970). The extinction of water samples from areas $\mathrm{B}, \mathrm{C}$ and $\mathrm{D}$ was measured in a photometer. The incident radiation was continuously recorded by a bimetallic actinograph on Helgoland. The wind data were provided by the meteorological station on the island.

\section{RESULTS}

\section{The red tide Gymnodinium}

At all stations (Fig. 1: A-F) the same Gymnodinium species was found, which had the following characteristics: The living dinoflagellate (Fig. 2a) measures about $30 \mu \mathrm{m}$ in length and $25 \mu \mathrm{m}$ in width. It is dorso-ventrally flattened with a convex dorsal and a concave ventral side. By light microscopy the periplast appears structureless. The marked left-handed girdle is placed towards the anterior portion of the cell (epicone). The sulcus is deeply grooved. Numerous yellowish-brown chromatophores are found in the protoplast. Attempts to culture the alga using Erdschreiber and modified Schreiber solutions failed.

The red tide dinoflagellate found by VAGN HANSEN \& SARMA (1969) off the Jutland coast at the same time was described by them as a Gymnodinium breve Davis forma. Gymnodinium breve is known and described from the Gulf of Mexico as a red tide organism (DAvis 1948). Although this species varies considerably in size and shape (see literature given by VAgn Hansen \& SARMa 1969), the Helgoland Gymnodinium species is unlikely to be a Gymnodinizm breve forma. Davis's original drawing (Fig. 2: $b$ and c) and description, and VAGN HANSEN \& SARMA's description of their Jutland material show the girdle to be equatorial, with no displacement. A further pronounced feature for the identification of Gymnodinium breve is a dome-like protuberance, ventrally overhanging, which is absent or weakly developed in the Jutland form and not found at all in the Helgoland Gymnodinium. The identification of the latter is therefore uncertain.

\section{Continuous observations at Helgoland Roads}

The measured parameters from water samples taken at Helgoland Roads ( $A$ in Fig. 1) during 22 July until 17 September, 1968, are plotted in Figure $3 a$ and b. Gymnodinium sp. is given as numbers and biomass (as carbon values). The biomass of other phytoplankton is indicated for 5 days. Chlorophyll a content of the seston, wind velocity and direction (DIR.), salinity and temperature of the water are plotted (Fig. 3a). Figure $3 b$ shows the nitrate and nitrite-nitrogen, phosphate and soluble organic carbon during the same period. 
On 2 August an increased number of Gymnodinium sp. with a high percentage of dividing stages was observed in the Helgoland plankton. On 14 August a first mass development of this species was found. After the peak of the bloom $\left(3.25 \times 10^{6} \mathrm{cells} / \mathrm{l}\right)$

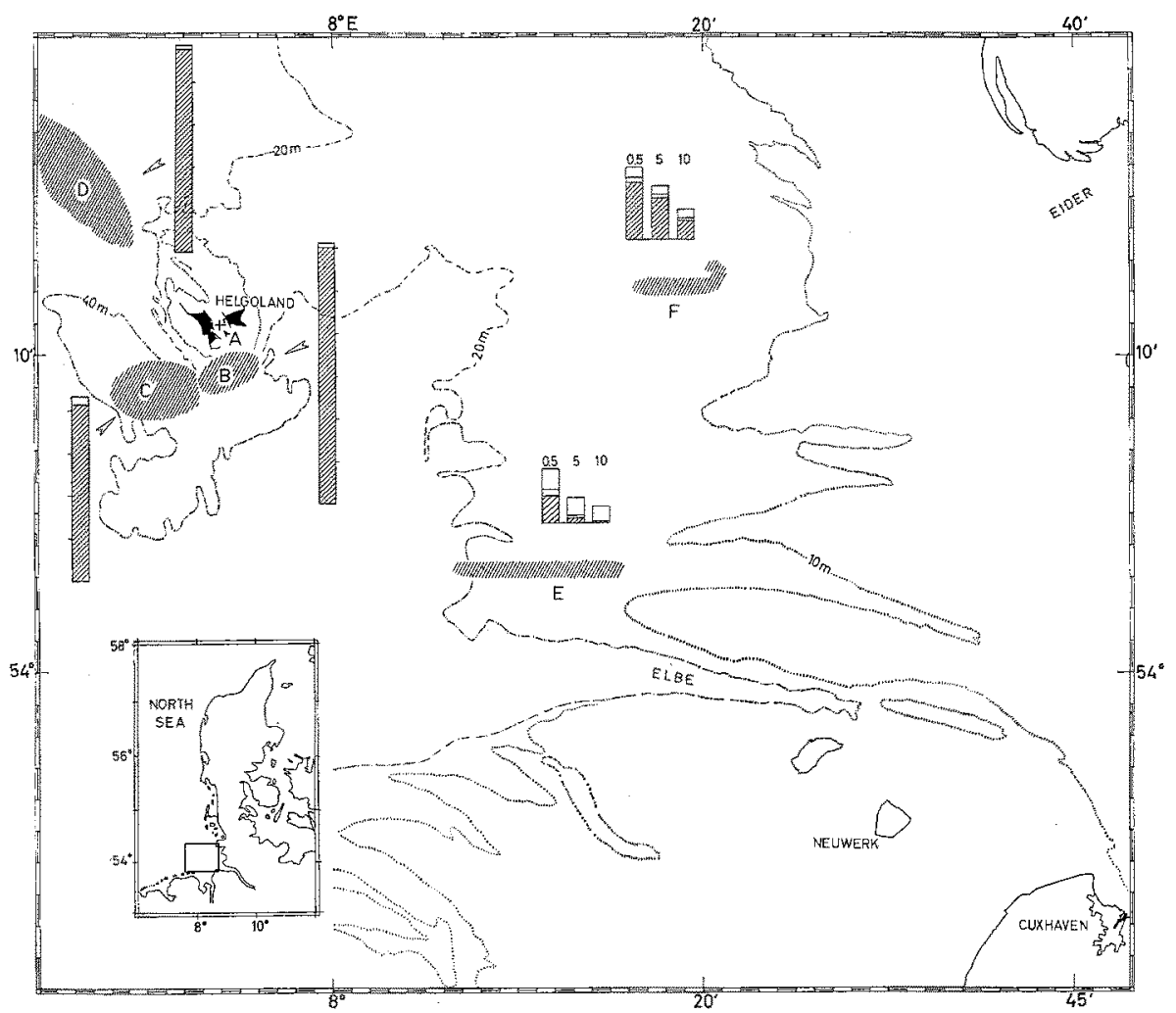

Fig. 1: Stations and areas where investigations have been made during the Gymnodinium bloom in August, 1968 in the Helgoland Bight. A: Helgoland Roads, permanently under observations. B, C and D: areas investigated on 27 and 28 August. In each area 4 stations with one vertical sample series have been made. The columns represent the mean total phytoplankton biomass (or mean Gymnodinium numbers) in a water column of $0-16.5 \mathrm{~m}$ depth. Scale: one mark at the columns is $500 \mu \mathrm{g} \mathrm{C/1}$ (or $500 \times 10^{3} \mathrm{G}$ ymnodinium/1). The shaded parts of the columns are Gymnodinizum biomass. $E$ and $F$ : drifting stations of 5-6 hours duration on 6 and 8 August. Columns represent the mean total phytoplankton biomass in $0.5,5$ and $10 \mathrm{~m}$ depth. The portions of diatoms, dinoflagellates except Gymnodinium, and of Gymnodinium sp. (shaded) are given from top to bottom of the columns. The scale is again $500 \mu \mathrm{g} \mathrm{C} / 1$

on 30 August the cell numbers suddenly decreased. The duration of the Gymnodinium bloom in the Helgoland waters was thus only 18 days. The chlorophyll curve, which parallels the numbers of Gymnodinium present, showed a marked decrease of phytoplankton from 23 to 26 August. The Gymnodinium carbon as a percentage of the total phytoplankton carbon was about $8 \%$ before the bloom (24 July), increasing to 92 and $96 \%$ during the bloom maximum, and decreasing to 79 and $89 \%$ on 11 and $13 \mathrm{Sep}^{-}$ tember, when Gymnodinitum numbers had declined (Fig. 3a). Of the other phyto- 
plankters only large Rbizosolenia species ( $R$ h. bebetata and $R b$. shrubsolei) were abundant until the beginning of August, followed later by Biddulphia sinensis and B. granulata. On 24 July the dinoflagellate Noctiluca miliaris was very abundant, with 1440 cells per liter forming $144 \mu \mathrm{g} \mathrm{C} / 1$ (as compared to the phytoplankton biomass of $230 \mu \mathrm{g} \mathrm{C} / 1)$. It decreased to $600 \mathrm{cell} / \mathrm{s} / \mathrm{on} 31 \mathrm{July}$ and was last found on 2 August. Counts of other microzooplankton revealed no abundant forms.

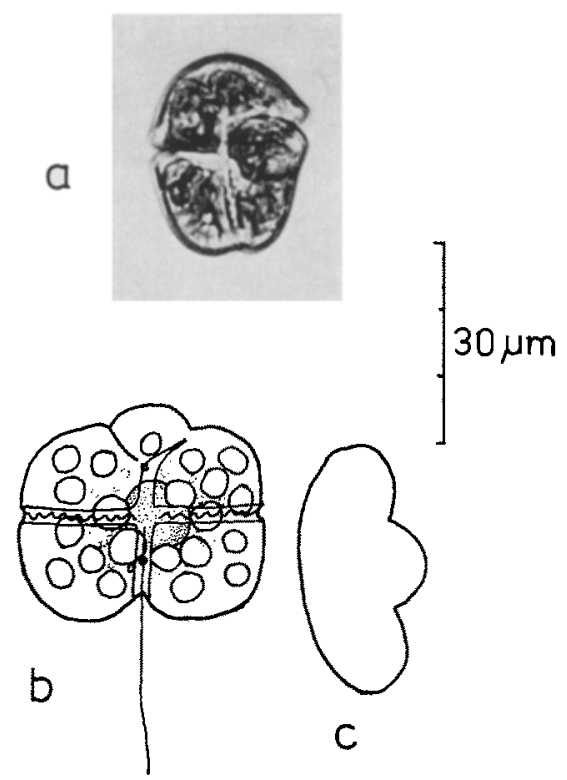

Fig. 2: a Gymnodinium sp. from Helgoland waters, August 1968. Photograph of the living cell, ventral view, showing the marked lett-handed girdle. $b, c$ Gymnodinium breve; ventral view (b) showing the equatorial girdle; apical view $(c)$ of the epicoie showing the overhanging process. (After Davis 1948, modified)

Measurements of phytoplankton production were carried out using the oxygen method in an incubator for 6 hours. In this period samples were illuminated with $20 \mathrm{cal} / \mathrm{cm}^{2}$, which is about the mean daily sum of incident radiation in the surface water layers near Helgoland. Before the onset of the Gymnodinium bloom phytoplankton production was about 0.112 to $0.15 \mathrm{mg} \mathrm{C} / \mathrm{l}$ in 6 hours. During the bloom period, $0.33,0.6$ and $0.293 \mathrm{mg} \mathrm{C} / \mathrm{l}$ were measured on 16,19 and 26 August, respectively. During the bloom peak assimilation measurement was carried out in a suspension of $3.7 \times 10^{6}$ Gymnodinium cells per litre, in which the larger diatoms had been removed. A production as high as $0.98 \mathrm{mg} \mathrm{C} / 1$ in 6 hours was measured using the full light intensity as mentioned above, $0.83 \mathrm{mg} \mathrm{C} / 1$ with $50 \%$ and $0.634 \mathrm{mg} \mathrm{C} / 1$ with $25 \%$ of that light intensity. This means that one million Gymnodinitim cells produced $0.265 \mathrm{mg}$ carbon in 6 hours in the incubator under natural light intensity. During the decline of the bloom in September, production values of $0.26,0.41$ and $0.068 \mathrm{mg} \mathrm{C} / 1$ were found on 2, 9 and 23 September, respectively. 
The relationship between chlorophyll $a$ and primary production during the Gymnodinium bloom was different from the normal relationship during other periods of the same year, where more diatoms and particularly more "dead chlorophyll" were included. A regression line for all values of chlorophyll $a$ and gross primary production $(\mathrm{n}=42)$ showed that $5.55 \mu \mathrm{g}$ chlorophyll $\alpha / 1$ caused a production of $1 \mu \mathrm{g} \mathrm{C} / \mathrm{l}$ in
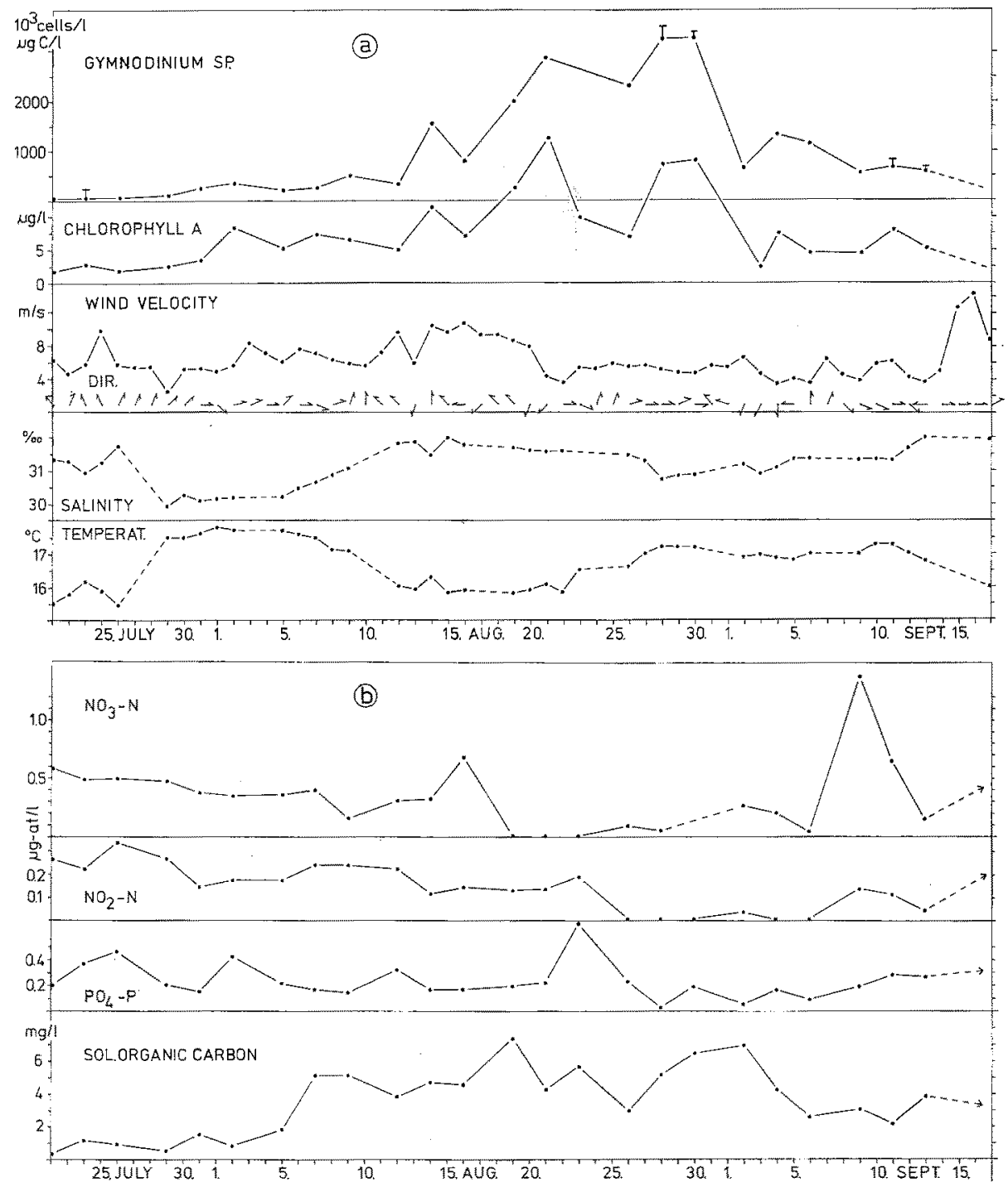

Fig. 3: a Parameters measured at Helgoland Roads (A in Fig. 1), July until September, 1968. Gymnodinium sp.: The scale numbers are cells per litre for Gymnodinium only, or $\mu \mathrm{g}$ carbon $/ 1$ for Gymnodinium as well as for total phytoplankton, which is plotted for 5 days (marked by a T-sign). Wind velocity in meters per second. Wind direction (DIR.): The arrows point in the direction (compass) where the wind is coming from. $b$ Parameters measured at Helgoland Roads. Micronutrients (in $\mu \mathrm{g}$-at/l) and soluble organic carbon (in $\mathrm{mg} / \mathrm{l}$ ) 
6 hrs., with $+0.58 \mu \mathrm{g}$ dhlor. a/ at zero production, which means "dead chlorophyll" $(\mathrm{r}=0.888)$. During the period under discussion (22 July to 23 September) this line was steeper $(6.68 \mu \mathrm{g}$ chlor. $a / 1$ correspond to $1 \mu \mathrm{g} \mathrm{C/l})$. A negative chlorophyll $a$ value $(-0.36 \mu \mathrm{g} / 1)$ was found at zero production $(\mathrm{r}=0.88)$. This indicates that pigments other than chlorophyll $a$ were included in primary production of the Gymnodinians.

Sechi disc readings ranged from $6.5 \mathrm{~m}$ before the bloom to $2.5 \mathrm{~m}$ during the bloom maximum. 4 to $5.5 \mathrm{~m}$ were measured during the first half of September. Although the influence of Gymnodinium numbers on the visibility was obvious, there was a poor correlation between these two parameters, since the tidal currents on Helgoland Roads cause resuspension of nonliving particles, which are the major cause of turbidity. Brownish discoloured patches were seen near Helgoland during the bloom period. On 23 August a discolouration of the heated sea water of the Helgoland swimming pool was observed with brownish masses of algae lying on the bottom of the pool.

As is obvious from Figure $3 \mathrm{a}$, high salinity was correlated with lower temperature, indicating a offshore water mass, which was found at Helgoland Roads following a period of northerly winds from 22 to 27 July, from 10 to 12 August and westerly winds from 8 to 12 September. Low salinity and higher water temperature indicate that the water masses east of Helgoland were influenced by coastal brackish water. During a period of easterly winds from 29 July to 8 August, these were drifted toward Helgoland. Five water masses could be distinguished during the period under discussion. It is obvious, therefore, that Figure 3 a shows not only the plankton succession, but in addition the sequence of water masses containing different plankton populations.

The hydrographical and planktological situation can be described as follows: During a period of north and northwest winds from 9 to 12 August a water mass of high salinity and low temperature reached Helgoland. A first increase of Gymnodinium numbers was found on 14 August correlated with a decrease of salinity and increase of temperature for just one day after the changing of wind directions on 13 August. On 19 August a Gymnodinium bloom was recorded, with a first peak on 21 August following a marked decrease of wind velocity. A low salinity, warmer water mass reached Helgoland Roads five days after the wind turned easterly on 22 August. The maximal Gymnodinium population was found in this coastal influenced water with cell concentrations reaching $3.25 \times 10^{6}$ per litre during a period of low easterly winds. As the wind direction changed from east to west, cell numbers and chlorophyll values suddenly had decreased on 2 and 3 September, apparently without great changes in salinity. On 4 September the Gymnodinium numbers had increased und subsequently decreased slowly during a period of continuous increase of salinity. Microscopic observations showed a high proportion of old Gymnodinium cells with no dividing stages.

During the decline of the Gymnodinium population there was a nitrate maximum on 9 September (Fig. 3b). The phosphate content generally was higher than $0.1 \mu \mathrm{g}$-at $/ 1$ during the bloom. Nitrite was very low from 26 August to 6 September, as were the nitrate values after the 20 August. The soluble organic carbon content was high during the bloom and was maximal during its decline. The counts of heterotrophic seawater bacteria (as assessed by the pour plate method using medium $2216 \mathrm{E}$ ): were increased

* These data were provided by Dr. W. Gunkel and H. H. Trekel (BAH). 
to $2500-3500$ per $\mathrm{ml}$ from 4 to 11 September as compared to $500-1000$ per $\mathrm{ml}$ before that time. There was no correlation between the recorded daily sum of total incident radiation with the plankton development.

\section{Observations near Helgoland}

The vertical stratification of plankton, chlorophyll $a$ and extinction of the water was measured in three areas about 2 nautical miles south, 3 miles southwest and 5 miles northwest of Helgoland (Fig. 1, B, C and D). These measurements happened to come to the same time when the bloom maximum appeared. The investigations in area $\mathrm{B}$ were carried out on 27 August from $10^{00}-11^{30}$ hours, in area $C$ on the same day from

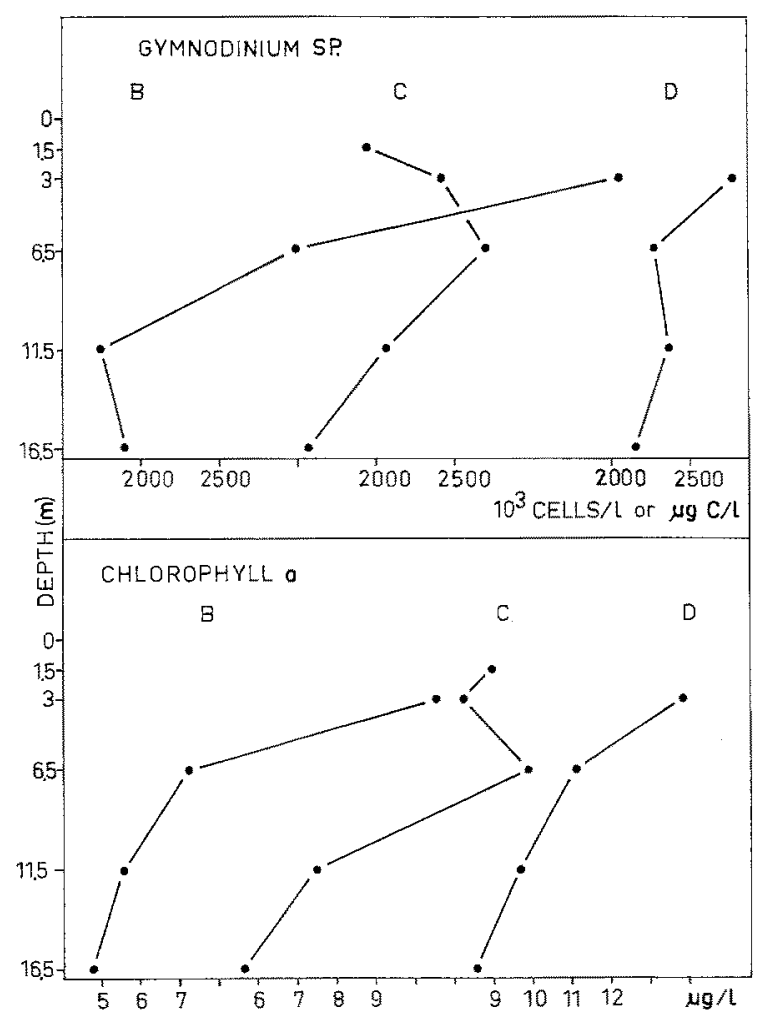

Fig. 4: Gymnodinium numbers and carbon and chlorophyll a content of the seston at areas B, $C$ and D near Helgoland. Mean values of 4 vertical series

$19^{30}-23^{30}$ hours and in area D on 28 August from $9^{50}-11^{00}$ hours. Four vertical series of water samples were taken in each area, approximately 2 nautical miles apart from each other to cover the exspected small scale heterogenity. Areas B and $\mathrm{C}$ are situated over the "deep trough", a depression of $45-60 \mathrm{~m}$ depth which is the deepest region in the German Bight. During the outgoing tide the water from area B partly moves north 
through the channel of Helgoland Roads. The water from area D (24 m water depth) reaches Helgoland Roads with the incoming tide. Whereas hydrographical stratification is not found in the channel due to vertical mixing by tidal currents, a stratified water column is found during calm weather periods in area $B$ and $C$, less frequently in area $D$.

Gymnodinium numbers found in areas $B, C$ and $D$ were similar to those at Helgoland Roads, however, the average Gymnodinium biomass as a percentage of the total phytoplankton biomass was higher $(98 \%, 96.6 \%$ and $98.6 \%$ in areas $\mathrm{B}, \mathrm{C}$ and $\mathrm{D}$, respectively). Aside from the Gymnodinians, only the diatom Biddulpbia sinensis was present in significant numbers. The vertical distribution of Gymnodinium varied considerably between morning and night samples in areas B and C (Fig. 4). The flagellates moved towards the surface during daylight hours and concentrated at a depth of approximately 6 meters during the night. A maximal Gymnodinium concentration of $7.76 \times 10^{6}$ per liter was found in area $B$ at $3 \mathrm{~m}$ depth at $11^{00}$ hours (no surface values were recorded). Different percentage of diatoms - which have a much higher (appr. 10 times) chlorophyll content - cause the differences in the vertical curves of Gymnodinium and chlorophyll (Fig. 4). In area $\mathrm{C}$ the diatom percentage of up to $25 \%$ was found in the upper $3 \mathrm{~m}$.

There was a poor correlation between chlorophyll a content and Gymnodinium numbers for the sum of all samples taken on 27 and 28 August $(r=0.41)$, but a very good correlation existed for distinctive groups of samples. The best one $(r=0.991)$ was found in area $B$ at $8^{20}-8^{40}$ hours. Correlation was similar for the other series of samples from area $\mathrm{B}$ and the first one from area $\mathrm{C}$, but then decreased rapidly later in the night. It was also poor in area.D. Calculating the regression coefficient it turned out that one million Gymnodinium contained not more than $3.5 \mu \mathrm{g}$ chlorophyll, when counts of other phytoplankton and of detritus were very low. But even in this case $1.1 \mu \mathrm{g}$ chlorophyll/1 was found at a zero Gymnodinium value. The correlation of Gymnodinium numbers and chlorophyll values from Helgoland Roads during the period of 22 July to 13 September was much better than for the samples mentioned above $(r=0.882)$. Only the values from September were correlated poorly $(r=0.39)$.

The Gymnodinium numbers were well correlated $(r=0.787)$ to the light extinction in the water (as measured in a photometer), especially in the samples where a good Gymnodinium/chlorophyll correlation was assessed. In these samples, one million cells per liter caused an extinction of $\mathrm{E}=0.083$ per $1 \mathrm{~m}$ measuring distance. The exeptionally high plankton concentrations had a dominant influence on the vertical extinction coefficient of the water, which is a rare circumstance for Helgoland waters, since usually the nonliving seston is the main cause of extinction.

\section{Observations at the nearshore Stations $E$ and F}

On 6 and 8 August, a short time before the Gymnodinium blooming occurred in the Helgoland waters, plankton and hydrography at two drifting stations near the coast were investigated. These stations were off the Elbe estuary near buoy "Großvogelsand-W" (Fig. 1: "E") with a water depth of about $15 \mathrm{~m}$, and off the mouth of the Eider near buoy "Außeneider" (Fig. 1: "F") on 8 August, with $14 \mathrm{~m}$ depth of 
water. An individual water mass in this shallow coastal area with strong tidal currents could be traced only if it was marked. A drifting cross of $2 \mathrm{~m}^{2}$ area, suspended from a small surface buoy, was exposed to the current at a depth of $5 \mathrm{~m}$. Following this buoy, water samples were taken in $0.5,5$ and $10 \mathrm{~m}$ depth at 30 minutes intervals for a total of $5-6$ hours.

The same Gymnodinium species as was found later near Helgoland was abundant at both stations. The mean composition of the phytoplankton biomass is given in

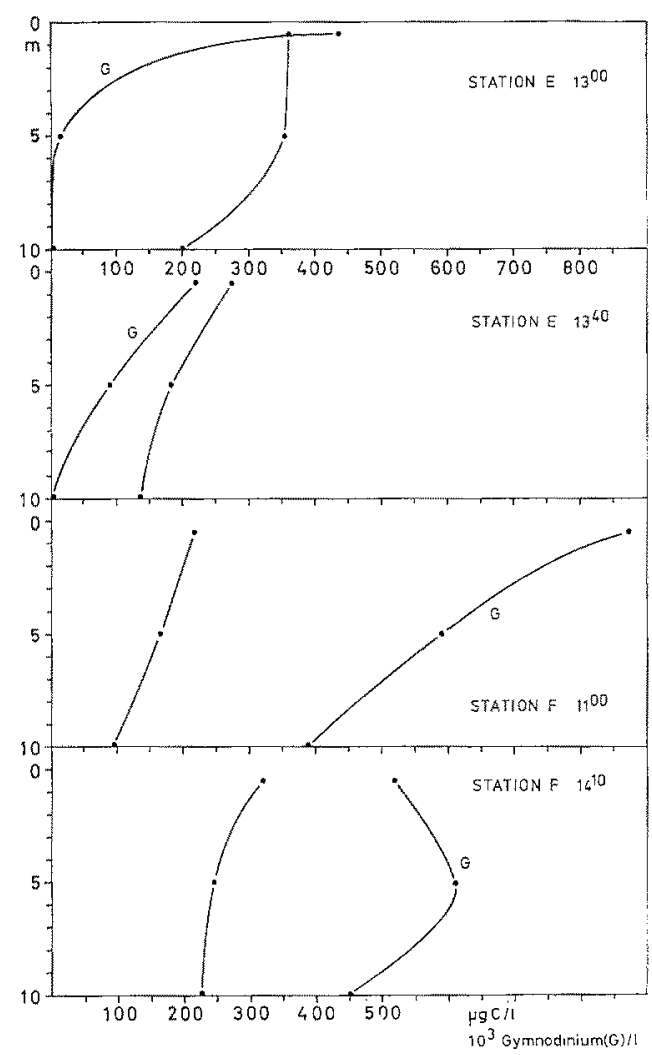

Fig. 5: Vertical distribution of Gymnodinium sp. "G", as numbers and carbon and other phytoplankton (as carbon). Two examples of extreme high and low vertical gradients at each of the drifting stations $E$ and $F$ with 5-6 hours duration. The time of sampling follows each station number

Figure 1. The maximal and minimal gradient in the vertical stratification of Gymnodinium (Fig. 5) were found in one case (station E) in two subsequent sample series within 30 minutes! This extreme small-scale heterogenity did not allow to investigate the plankton succession. From most of the vertical series it was evident that the Gymnodinium cells can concentrate in the upper meters even during the period of maximal tidal current, which in this case reached a velocity of 1.1 to 1.8 nautical miles per hour. This must be of great significance for the organic production of these flagellates 
in the turbid water off the Elbe estuary, where a Secchi disc visibility of 2.2 to $2.8 \mathrm{~m}$ was found, corresponding to an estimated compensation depth of only 6.8 to $8.6 \mathrm{~m}$.

At station $F$, north of station $E$ and more remote from the mudflats of the German Waddensea, twice as many Gymnodinium sp. $(646,000 / 1)$ were found, in addition to increased numbers of other phytoplankton. The drift of water masses by tidal current was 0.6 to 1.4 nautical miles per hour. The salinity at station $F$ was about $30.4 \%$ at all depth compared to $30.0 \%$ at the surface and 30.3 to $30.6 \%$ at $10 \mathrm{~m}$ depth by station $\mathrm{E}$. These are high salinities for the area, indicating that no substantial mixing with river water took place. The seston dry weight in the stratified water column of station $\mathrm{E}$ was about $4.2 \mathrm{mg} / \mathrm{l}$ in the upper $5 \mathrm{~m}$ and $9.1 \mathrm{mg} / \mathrm{l}$ at $10 \mathrm{~m}$. In the unstratified water of station $F$ it was $3.5 \mathrm{mg} / \mathrm{l}$ at all depth, where it decreased to half of that value during the time of observation. There was a higher Secchi disc visibility at station $F$ with 3.5 to $4.2 \mathrm{~m}$, corresponding to an estimated compensation depth of 10.5 to $12.8 \mathrm{~m}$. As the compensation depth might have nearly reached the bottom, the higher standing stock without a vertical stabilisation of the water column is explained.

\section{DISCUSSION}

VAGN HANSEN \& SARMA (1969) started sampling of plankton after the occurrence of fish mortality in the beginning of October, 1968, when brown discoloured patches were observed within the 20-m-line off Esbjerg and north of Tyboron up to Skagen. Fishermen had seen discoloured patches during July west of Limfjorden, which became more widespread during August and til 9 October. These patches and the subsequent poisoning of fish could be easily attributed to the blooming of Gymnodinium breve forma. In the Esbjerg region, this dinoflagellate was found in cell concentrations of 2 to 8.5 millions per litre in the bloom patches, and it formed 96 to $99.9 \%$ of total plankton counts. North of the Limfjord cell numbers were much lower ( 1 to 2 millions per litre, of which 92 to $98 \%$ were Gymnodinium). Concentrations might have been much higher during the bloom. Daily samples, collected from 16 October in Esbjerg harbour and in the Limfjord at Nykøbing, showed up to 1 million cells/1 in Esbjerg harbour until the beginning of November, although the discoloured patches had disappeared by the middle of October. In the middle of November, cell numbers decreased rapidly. The cell counts in the Limfjord were much lower (at most 300 000/1). During R.V. "Dana" cruise during October 14 to 16, the greatest cell concentrations occurred north of the Limfjord (982 000/1 at the surface), but no discolouration developed.

VAGN HANSEN \& SARMa made their investigations when the bloom maxima probably were over and at a time when no blooms were observed in the Helgoland Bight farther south. Only the fishermen's observations of discoloured patches indicate that red tides occurred off the Jutland coast at the same time as in the Helgoland Bight. The numbers of Gymnodinium sp. in the farther offshore waters of Helgoland were comparable to those found by VAGN HANSEN \& SARMA. The Gymnodinium biomass made up 92 to $96 \%$ of total phytoplankton in the mixed water of Helgoland Roads and 96 to $99 \%$ of biomass carbon south and northwest of the island during the bloom 
maximum. Cell concentrations of about 3 millions per litre caused a brownish water discolouration. According to VAgn Hansen \& SARma at least 1 million cells/1 are necessary to bring about visible red water. Thus, the fishermen's observations off the Jutland coast would indicate that Gymnodinium was blooming there at concentrations of at least 1 million cells/l from July to the beginning of October, when patches disappeared during a breeze.

The formation of bloom patches is known from the red tide research in the United States. Holmes et al. (1967) describe 5 red water dinoflagellate blooms in La Jolla Bay, where cell concentrations reached up to 20 millions per litre. During the day organisms, consisting partly of Gymnodinium spp., appeared in dense patches and apparently dispersed at night. Cells must have concentrated both vertically and horizontally to account for the numbers observed. A phototaxis-dependant mechanism forming bloom patches of Pyrodinium bahamense in a shallow bay was described by SELIGER et al. (1970). EPpley et al. (1968) report the evidence for a cellular periodicity in vertical migration of dinoflagellates. Even in the densest patches Houmes et al. found the cells to be physiologically active. The decline of blooms was associated with an increase of dissolved organic carbon - as it was found at Helgoland Roads in September, 1968. PraKash (1967) described that dying cultures of Gonyaulax tamarensis release their toxin into the medium, which fact may contribute to an explanation for the death of sand eels off the English East Coast one week after the Gonyaulax tamarensis maximum occurred there in 1968 (CLARK 1968, INGHAM et al. 1968).

Absence of wind and high insolation are considered by RYTHER (1955) to be universal factors for red tide appearance in coastal waters. Amongst the different factors which may cause red tides, reviewed by Rounsefell \& Nexson (1966), low wind speed together with special chemical water properties are most important. "It seems to be well established that red tide organisms can and do bloom when nutrient levels are low", they state. Red tides often occur immediately following a diatom bloom which has used up inorganic nutrients. Low inorganic nitrogen levels and high organic carbon content characterize also the bloom water at Helgoland Roads (Fig. 3b). The possible influence of external metabolites on dinoflagellate blooms are discussed by RouNSEFELL \& Nelson. Prakash (1967) and Prakash \& Rashid (1968) found that the presence of high concentrations of humic acid sustained growth of several Gonyaulax species much better in culture as well as in situ than a medium which lacked this substance. The rich content of humic substances in the Inner German Bight (measured as "Gelbstoff" by Kalle 1956) might thus have had ecological significance for the red tide Gymnodinium there.

A steep, shallow thermocline was associated with the blooms in La Jolla Bay (Holmes et al. 1967). Stuch distinct discontinuity layers are not usually found in the coastal areas of the south-eastern North Sea because of vertical mixing caused by strong tidal currents. These have a velocity up to 80 to $100 \mathrm{~cm} /$ second in the Inner German Bight. The mixing due to tidal currents might be responsible for the lower cell concentrations as compared to red tides in the Gulf of Mexico and off La Jolla. There was no indication for stabilisation of the water column off the Elbe estuary by river water outflow. The freshwater discharge from the Elbe river was at a minimum in August 1968. The salinity near the isle of Neuwerk in the outer Elbe estuary increased 
from $26 \%$ on 13 August to about $28 \%$ on 14 August (KüHL 1968). High salinity and low temperature $\left(14.2^{\circ}\right.$ to $\left.17.5^{\circ} \mathrm{C}\right)$ were recorded there until 21 August. Also at stations $\mathrm{E}$ and $\mathrm{F}$ in the beginning of August salinities relatively high for this area were found, so that direct influence of river water discharge on bloom forming conditions can be excluded. The relatively stable water column stratification during an unusually long period of calm wind and warm weather certainly account for the widespread occurrence of red tides in the summer and autumn of 1968 in the south eastern North Sea. From May until the beginning of the blooms there was not one stormy day. The mean daily wind velocity was Beaufort 6 on one day, 5 on 10 days, and the rest Beaufort 2-4.

As water masses containing Gymnodinium blooms were characterized by low salinity and high temperature, both indications for the nearshore water, the observations of Helgoland Roads suggest that the blooms developed in the water east of Helgoland. Here, half-way between the island and the North Frisean Coast, the convergence zone of the German Bight is located (GOEDECKE 1941).

There was no evidence that the total radiation was a limiting factor for the blooms. In the North Sea variations in total daylight are small during the summer as compared to the great changes of underwater light conditions due to change of seston content, which depends on vertical mixing of the water column and resuspension of sedimented material.

The 1968 red tides seem to be the first occurrences of this kind described from the North Sea. It might well be possible, however, that even large blooms of small dinoflagellates have not been detected in former years. According to Vagn Hansen \& \& SARMa (1969) the Gymnodinium breve forma from the Jutland waters was very poorly preserved by formaldehyde and disintegrated within 3 to 5 days. This means that the organism might have been missed completely in the older plankton samples. The Gymnodinium sp. from Helgoland waters was fairly well preserved in Lugol's solution (of higher concentration as recommended!). Even after several month of storage we could not find any evidence of disintegration, though morphological studies were no longer possible. The continuous plankton recorder survey (HARDY 1939) was recently extended by RoBINSON (1969) to an at least qualitative survey of Gonyaulax distribution in the North Sea. It could be proven that the occurrence of G. tamarensis was widespread even in 1969, but in numbers much lower than in 1968.

Red water caused by swarming of Noctiluca miliaris during calm weather conditions at the sea surface is observed every summer in the southern North Sea. These patches, usually in long, narrow, parallel bands often correlated with convergences, might be confused with potentially poisonous dinoflagellate red water by unexperienced observers. Reports of discoloured patches can be used as indication for a red tide only after microscopic identification of the plankton involved.

The first evidence for poisonous red tides are still the secondary effects: dead fish or seabirds washed ashore, or human illness after eating shellfish. Shags have proven to be sensitive indicators for a poisoned food chain (Woon 1968). As animal poisoning occurs only several weeks after the onset of the bloom, no systematical investigations of the conditions leading to bloom formation are possible any longer. To permit this a bloom would have to occur in an area under permanent hydrographical, chemical and 
planktological investigation. The station Helgoland Roads, where such observations are being made, was only touched for brief periods by water masses containing blooms. Many more stations of this kind are needed for a systematical red tide survey in such a heterogenous coastal water. Fortunately, other plankton investigations have been made (stations B-F) without realizing that a bloom was going on, but nevertheless of some use for analyzing it afterwards.

Even if the Helgoland Gymnodinium had been poisonous - an assumption for which we have no evidence - the chances of observing killed animals would have been poor. The blooms lasted for only 18 days at Helgoland Roads, and neither man nor seabirds exploit the clams growing near Helgoland (there are only few ducks). Guillemots, which might be affected, have a rookery on Helgoland, but left it befor the red tides occurred. Washing ashore of dead fish is not very likely considering the shoreline of only a few hundred meters.

\section{SUMMARY}

1. As in other parts of the North Sea, dinoflagellate red tides occurred in Helgoland waters in August, 1968. Measurements of plankton, and physical and chemical water properties at the permanent station "Helgoland Roads" were analyzed to describe the blooms. In addition, planktological and hydrographical investigations at three areas south, southwest and northwest of Helgoland on 27 and 28 August, as well as at two drifting stations off the mouths of the Elbe and Eider rivers on 6 and 8 August, were used for this work.

2. Gymnodinium sp. was abundant at all these localities, forming blooms near Helgoland from 14 to 30 August, with a maximum of 3 to $3.25 \times 10^{8}$ cells $/ 1$ (and 18 to $19 \mu \mathrm{g}$ chlorophyll $a / 1)$ on 28 and 30 August at Helgoland Roads. The primary production was as high as $0.98 \mathrm{mg} \mathrm{C} / 1$ in 6 hours in a suspension of $3.7 \times 10^{6} \mathrm{Gym}$ nodinium $/$, where diatoms had been removed. This means that one million Gymnodinium produced $0.265 \mathrm{mg} \mathrm{C}$ in 6 hours. At Helgoland Roads nitrate and nitrite were depleted at times, but not phosphate.

3. About $3 \times 10^{6}$ Gymnodinium sp./I were found in the upper $16.5 \mathrm{~m}$ of water investigated around Helgoland on 27 and 28 August (maximal $7.8 \times 10^{6}$ cells/ 1 at $3 \mathrm{~m}$ ). There was a marked vertical stratification of Gymnodinium with a concentration towards the surface during the day. This was particularly the case in the turbid water off the Elbe estuary, where numbers up to $0.3 \times 10^{6} / 1$ were counted. Gymnodinium sp. formed 96 to $99 \%$ of the phytoplankton biomass during maximal development. The chlorophyll a content of one million Gymnodinium was only $3.5 \mu \mathrm{g}$. An extinktion of $\mathrm{E}=0.083 / 1 \mathrm{~m}$ was measured in a suspension of $10^{\circ} \mathrm{Gym}-$ nodinium $/ 1$ in samples with minimal other plankton and detritus.

4. The water masses containing Gymnodinium blooms, which reached Helgoland after a change of wind direction, were characterized by lower salinity and higher temperature. This indicates that blooms developed in the coastally influenced water masses east of Helgoland. The red tides occurred during a period of minimal discharge of Elbe river water and of relatively high salinity of the coastal water in the 
Inner German Bight. They developed after a long period of calm winds. There were no records of reported fish or shellfish poisoning.

Acknowledgements. The authors wish to thank Miss D. Colbourn, Miss U. Wried and Mr D. VenABLE for valuable assistance in plankton counting. Miss U. Volz, Mr. E. H. Harms and Mr. K. TReutNer carried out hydrographical and chemical measurements.

\section{LITERATURE CITED}

Adams, J. A., Seaton, D. D., Buchanan, J. B. \& Longbottom, M. R., 1968. Biological observations associated with the toxic phytoplankton bloom off the East Coast. Nature, Lond. 220, 24-25.

Beobachtungen auf den Deutschen Feuerschiffen der Nord- und Ostsee im Jahre 1968, 1970. Meeresk. Beob. Ergebn. dt. hydrogr. Inst. 30.

CLARK, R. B., 1968. Biological causes and effects of paralytic shellfish poisoning. Lancet 2, $770-772$.

Coulson, J. C., Potrs, G. R., Dean, I. R. \& Fraser, S. M., 1968. Mortality of shags and other sea-birds caused by paralytic shellfish poison. Nature, Lond. 220, 23-24.

Davis, C. C., 1948. Gymnodinium brevis sp. nov,, a cause of discoloured water and animal mortality in the Gulf of Mexico. Bot. Gaz. 109, 358-360.

Fraser, J. H. \& Seaton, D. D., 1969. Scottish plankton collection, 1968. Annls biol., Copenh. $25,91-93$.

GrLlbright, M., 1957. Ein Verfahren zum oxydativen Nachweis von organischer Substanz im Seewasser. Helgoländer wiss. Meeresunters. 6, 76-83.

GLover, R. S. \& Robinson, G. A., 1969. The continuous plankton recorder survey: plankton around the British Isles during 1968. Annls biol., Copenh. 25, 87-91.

GoedeCKE, E., 1938. Unperiodische Wasserversetzungen in der Deutschen Bucht. Rapp. P.-v. Réun. Cons. perm. int. Explor. Mer 108 (3), 89-92.

- 1941. Beiträge zur Hydrographie der Konvergenz der Deutschen Bucht. Annln Hydrogr. Berl. 69, 345-362.

HARDY, A. C., 1939. Ecological investigations with the continuous plankton recorder: object, plan and methods. Hull Bull. mar. Ecol. 1, 1-57.

Holmes, R. W., Winlifams, P. M. \& Eppley, R. W., 1967. Red water in La Jolla Bay, 1964 to 1966. Limnol. Oceanogr. 12, 503-512.

InGHAM, H. R., Mason, J. \& Wood, P. C., 1968. Distribution of toxin in molluscan shellfish following the occurrence of mussel toxicity in North-East England. Nature, Lond. 220, 25-27.

Kalle, K, 1934. Meereskundlich-chemische Untersuchungen mit Hilfe des Zeiss'schen PulfrichPhotometers. III. Mitteilung: Methodische Untersuchungen der Phosphatgehaltsbestimmung. Annln Hydrogr. Berl. 62 (2/3).

- 1956. Chemisch-hydrographische Untersuchungen in der inneren Deutschen Bucht. Dt. hydrogr. Z. 9 (2), 55-65.

KÜHL, H., 1968. Wassertemperatur und Salzgehalt an der "Alten Liebe" - Cuxhaven und bei der Insel Neuwerk im Jahre 1968. Veröff. Inst. Küst.- u. Binnenfisch. 44, 1-23.

Lohmann, H., 1908. Untersuchungen zur Feststellung des vollständigen Gehaltes des Meeres an Plankton. Wiss. Meeresunters. (Abt. Kiel) 10, 129-370.

McAlice, B. J., 1970. Observations on the small-scale distribution of estuarine phytoplankton. Mar. Biol. 7, 100-111.

McCollum, J. P. K., Pearson, R. C. M., Ingham, H. R., Wood, P. C. \& Dewar, H. A., 1968. An epidemic mussel poisoning in North-East England. Lancet 2, 767-769.

Muldin, M. M., Sloan, P. R. \& Eppley, R. W., 1966. Relationship between carbon content, cell volume, and area in phytoplankton. Limnol. Oceanogr. 11, 307-311. 
Neumann, H. \& Meier, C., 1964. Die Oberflächenströme in der Deutschen Bucht. Dt. hydrogr. Z. $17(1), 1-40$.

OTro, L., 1967. Investigations on optical properties and water masses of the southern North Sea. Neth. J. Sea Res. 3, 532-552.

PraKash, A., 1967. Growth and toxicity of a marine dinoflagellate, Gonyanlax tamarensis. J. Fish. Res. Bd Can. 24, 1589-1606.

- \& RAshid, M. A., 1968. Influence of humic substances on the growth of marine phytoplankton: dinoflagellates. Limnol. Oceanogt. 13, 598-606.

Robinson, G. A., 1968. Distribution of Gonyaulax tamarensis Lebour in the western North Sea in April, May and June, 1968. Nature, Lond. 220, 22-23.

- 1969. Distribution of Gonyaulax tamarensis Lebour in the western North Sea in 1969. Coun. Meet. int. Coun. Explor. Sea (= C.M.-I.C.E.S.) 17.

Rounsefell, G. A. \& Nel.son, W. R., 1966. Red-tide research summarized to 1964 including an annotated bibliography. Spec. scient. Rep. U.S. Fish Wildl. Serv. (Fisheries) 535, 1-85.

RYTHER, J. H., 1955. Ecology of autotrophic marine dinoflagellates with reference to red water conditions. In: The luminescence of biological systems. Ed. by F. H. JoHnson. A.A.A.S., Lancaster, Pa. 387-414.

Seliger, H. H., Carpenter, J. H., Loftus, M. \& McElroy, W. D., 1970. Mechanisms for the accumulation of high concentrations of dinoflagellates in a bioluminescent bay. Limnol. Oceanogr. 15, 234-245.

SMAYDA, T. J., 1965. A quantitative analysis of the phytoplankton of the Gulf of Panama. II. On the relationship between $\mathrm{C}^{14}$ assimilation and the diatom standing crop. Bull. InterAm. trop. Tuna Commn 9 (7), 466-529.

Strathmann, R. R., 1967. Estimating the organic carbon content of phytoplankton from cell volume or plasma volume. Limnol. Oceanogr. 12, 411-418.

Strickland, J. D. H. \& Parsons, T. R., 1965. A manual of sea water analysis. Bull. Fish. Res. Bd Can. 125, 1-203.

THOMSEn, A., 1968. Hydrography of the south-eastern North Sea 1968, danish observations. Annls biol., Copenh. 25, 59-60.

TsujrTa, T., 1968. On red water oceanography. Bull. Plankt. Soc. Japan 15 (2), 1-9.

VAGN HANSEN, K. \& SARMA, V., 1969. On a Gymnodinium red water in the eastern North Sea during autumn 1968 and accompanying fish mortality with notes on the oceanographic conditions. Coun. Meet. int. Coun. Explor. Sea (= C.M.-I.C.E.S.) 21.

VISSER, M. P., 1967. Secchi disc and sea colour observations in the North Atlantic Ocean during the Navado III cruise, 1964-65, aboard H. Neth. M.S. "Snellius" (Royal Netherlands Navy). Neth. J. Sea Res. 3, 553-563.

- 1970. The turbidity of the Southern North Sea. Dt. hydrogr. Z. 23 (3), 97-117.

WrLson, W. B., 1967. Forms of the dinoflagellate Gymnodinium breve DAvis in cultures. Contr. Mar. Sci. 12, 120-134.

Wood, P. C., 1968. Dinoflagellate crop in the North Sea. Introduction. Nature, Lond. 220, 21.

First author's address: Dr. W. HrckeL

Biologische Anstalt Helgoland

(Zentrale)

2 Hamburg 50

Palmaille 9

Federal Republic of Germany 